\title{
'OCEAN OF STORIES': an introduction
}

\section{Transforming Cultures eJournal, \\ Vol. 4 No 2 November 2009 \\ http://epress.lib.uts.edu.au/journals/TfC}

\section{Devleena Ghosh \& Lola Sharon Davidson ${ }^{1}$}

In In an Antique Land, Amitav Ghosh speaks of his surprise when he arrives at a "quiet corner" of the Nile Delta to find that the men of the village had "the busy restlessness of airline passengers in a transit lounge". He finds that their grandparents, relatives and ancestors had migrated too so that people had surnames originating in the Sudan, the Levant or Turkey. For Ghosh, ethnography was not an intensive dwelling in place but a dwelling in flows and movements, a trope that is reinforced when further on in the book, Ghosh engages in a shouting match with an imam about whose country is more advanced and modern. Ghosh says in despair, "Despite the vast gap that lay between us, we understood each other perfectly. We were both traveling - in the West". 2

Following on from our 2008 (3: 2) issue Cultural Currents of the Indian Ocean, this issue focuses on the connections between the colonies and former colonies of the Indian Ocean and the contested identities which arise from complex cultural interactions. The articles all consider how communication - the composing and telling of some stories as well as the repression of others, using words, images and material cultures - has shaped identities and interactions in the Indian Ocean.

\footnotetext{
${ }^{1}$ Devleena Ghosh is Associate Professor at the University of Technology Sydney and co-ordinator of the Indian Ocean and South Asian Research Network. She is the author of Colonialism and Modernity (UNSW Press, 2007, with Paul Gillen) and editor of Cultures of Trade: Indian Ocean Exchanges (Cambridge Scholars Press, 2007, with Stephen Muecke), Water Borders and Sovereignty in Asia and Oceania (Routledge, 2008, with Heather Goodall and Stephanie Hemelryk Donald) and Women in Asia: Shadowlines (Cambridge Scholars Press, 2010).

Lola Sharon Davidson is the Research Assistant for the ARC projects, Intercolonial Networks of the Indian Ocean and Culture and Commerce in the Indian Ocean, hosted by the University of Technology Sydney. She is the author of Australia's First Bank: Fifty Years from the Wales to Westpac (UNSW Press, 2005) with Stephen Salisbury and editor, with Devleena Ghosh, of "Cultural Currents of the Indian Ocean", Special Issue. Transforming Cultures eJournal 3:2 (2008). Her article "Woven Webs: Textiles and Trade Networks in the Indian Ocean" is appearing next year.

${ }^{2}$ Amitav Ghosh (1992) In an Antique Land, London: Granta Books: 236.
} 
This is an ongoing discussion in a wider project which is tracing the way that the $18^{\text {th }}$ and $19^{\text {th }}$ century empires set up conduits along which people, technologies, ideas, plants and sometimes animals moved in all directions without necessarily either the knowledge or the control of imperial regimes. Attempts were increasingly made by imperial bureaucracies to regulate the movement and employment of lascars, camelmen, hawkers, plantation labourers and tourists through processes of documentation, classification and surveillance. However, despite these controls, people flowed in, out and between metropoles and colonies, generating diasporas that were beyond the vision as well as the reach of empire.

Formal and informal movements of peoples and ideas in imperial spaces force a reevaluation of the old binaries of colony and empire, home and the world, metropole and periphery, highlighting previously unexpected and uncovered connections and relationships between spaces that previously seemed discrete. The relationships of power do not disappear but subject peoples are able to subvert them in ways that blur those categories, making them contingent and relational. As many scholars have pointed out, these flows and contacts are crucial sites for an unfinished modernity. ${ }^{3}$ "Euroimperial travel", according to Inderpal Grewal, became incorporated into the lives of colonized people as past of the disciplinary apparatus of colonial modernity in the nineteenth century. ${ }^{4}$ Focusing on these networks and flows offer some interesting comparisons between the colonized gaze and the imperial one, a peripheral vision that lurks just outside the corner of the eye. These articles on the racialised and gendered hierarchies of the Indian Ocean and the construction of colonial modernity present a unique perspective on the ancient "Ocean of Stories".

Our first section, Communicating and Connecting, opens with a theoretical reflection from Anne K. Bang on the relation between the global and the local. Using three sources relevant to the spread of Islam in the south-west Indian Ocean, Anne interrogates the multiple perspectives from which these fragments of information might be contextualised and hence become part of a narrative anchored to a particular spatiotemporal moment. Michael Pearson then takes up the practicalities of cross-cultural

\footnotetext{
3 J. Clifford (1997) Routes: Travel and Translation in the Late Twentieth Century, Cambridge Mass.: Harvard University Press.

${ }^{4}$ Inderpal Grewal (1996) Home and Harem: Nation, Gender, Empire, and the Cultures of Travel, Durham, Duke University Press: 14-15.
} 
communication when the parties to the exchange do not speak the same language. Obviously intermediaries were valuable but they were not always available, while even the sophisticated Indian system of trading through concealed hand signals had its limitations. Pearson concludes that a variable version of Arabic was widely used by Indian Ocean traders and this was supplemented to some extent with Portuguese when dealing with Europeans.

Our second section, Floating Identities, examines the plight of two groups whose identities have been challenged by migration from their homeland. Susan Philip's reading of two plays by the Malaysian Indian author, K.S. Maniam, show him to be engaged in a determined deconstruction of the essentialising notions of cultural and ethnic identity promoted by the Malaysian government. Through his characters, Maniam demonstrates the contradictions underlying a superficial attribution and adoption of an inflexible identity based on origin and argues instead for a fluid and hybrid identity which allows the individual the freedom to evolve in the continuing story connecting their past, present and future. In our next article the emphasis shifts to the attitudes of the wider society to the newcomers. Whereas the Malaysian Indians were brought by the British as plantation workers, Africans were taken to the East Indies by the Dutch to serve as soldiers and policemen. This role was not calculated to endear them to their new neighbours and would inevitably become problematic with Indonesian independence when most chose to move to the Netherlands rather than return with their Indonesian families to an Africa by now quite unfamiliar. Ineke van Kessel examines the racial stereotypes underlying and supporting the colonial labour regime and points to the dilemma posed by the African's ambiguous position, poised above the colonised Indonesians but below their European masters.

Our third section, Contesting Identities, develops further the themes of ascription and resistance. Julia Martinez looks at labour activism among pearling crews working in the waters between the Dutch East Indies and Australia before the end of the Second World War. These workers were classified as Malays and communication between them and their white employers was often hampered by linguistic incomprehension. During the nineteenth century, institutional power lay entirely with the whites and Malay resistance most frequently took the form of armed mutiny, but by the 1920s and 1930s the Malay crews had established relations with the Australian union movement and, together with 
a more favourable environment of increased government labour regulation, this enabled them to pursue their negotiations and defend their rights in a less violent and more consistently effective manner.

Stories about and by the peoples of the Indian Ocean have been used in the politics of the past - but also in the present. The final two articles consider news media and the way representations have shaped power relations but have also been contested. Heather Goodall examines the reports generated in Australia about the campaign for Indonesian independence at the end of the Second World War which involved both Australian waterside unions and the union of Indian seamen in Australia, who united to block the shipment of arms to facilitate the Dutch repossession of the islands. Goodall argues that old stereotypes were mobilised which consistently obscured the pivotal role of the Indian seamen in both mainstream newspapers and in left wing film. At the same time, however, Indian seafarer activists intervened in news stories to leave traces of a very different view. Today, persistent representations of Indians as passive and of all Muslims as fanatical may still be operating in contemporary Australian media presentation of recent conflicts, but the South Asians involved are themselves also seeking to reshape the stories.

Contemporary media stereotypes are equally the subject of the final paper in this section which discusses the recent Chikungunya epidemic on Réunion Island. It took a surprisingly long time for the local press to realise the severity of the epidemic and an even longer time for the metropolitan press to do so. In part this would appear to be due to a perception that such events are a normal part of life in the tropics together with a certain marginalisation of distant places even though they are, strictly speaking, part of France. Different cultural attitudes to disease further complicate the issue of response in a multicultural context.

Our issue concludes with a paper by Jeremy Prestholdt on the culture of material consumption in Zanzibar during the nineteenth century. This paper is in a non-refereed section of the journal since much of the material has already been published in the author's monograph, Domesticating the World: African Consumerism and the Genealogies of Globalization. It is included here for its relevance to our Indian Ocean theme. The enthusiasm for foreign goods shown by the wealthy inhabitants of the 
cosmopolitan trading centre of Zanzibar was far from a passive acceptance of the Western, the Arabic, the Indian or even the modern but rather a creative engagement with global flows and their integration into a valid and specific social practice unique to this time and place. With this paper the circle is completed, as we return to the theme of negotiation and accommodation between the local and the global with which we started, having hopefully shed some light along the way on the complex and shifting interactions of people, goods and ideas around the Indian Ocean 